\title{
EU BORDER MANAGEMENT AFTER THE LISBON TREATY
}

\begin{abstract}
Jorrit Jelle Rijpma*
Summary: This article looks at how the Lisbon Treaty will affect the management of the EU's external borders. It examines the current treaty framework and the way in which the Community has made use of its powers in this policy field. It discusses the changes the Lisbon Treaty is likely to bring about and gives a short overview of how the future management of the external borders is taking shape in the absence of ratification of the Lisbon Treaty. The underlying theme of this contribution is the distinction between legislation and operational co-operation in this policy field. It points out a number of problems with the approach of fostering integration in the Area of Freedom, Security and Justice through operational co-operation. It is argued that the Lisbon Treaty fails to provide a sounder legal framework for the EU's joint operational activity in the AFSJ as a whole and the management of the external borders in particular.
\end{abstract}

\section{Introduction}

This article will examine how the Lisbon Treaty will affect the management of the EU's external borders. ${ }^{1}$ The underlying theme of this contribution is the distinction between legislation and operational co-operation in this policy field. Although external border management may be considered exemplary concerning developments in the Area of Freedom, Security and Justice (AFSJ) as a whole, it is unique in forming the only 'police power' currently covered by the First Pillar of the EU. This article will first look at the meaning of 'EU external borders' and the current treaty framework for the management thereof. It will then consider how the Community has made use of its powers. It will continue with an examination of the changes the Lisbon Treaty is likely to bring about. The article will conclude with a short overview of how the future management

\footnotetext{
* Jorrit Jelle Rijpma, Researcher, Law Department, European University Institute, Florence, Italy.

${ }^{1}$ For the purpose of this paper, the term 'management of external borders' is understood as the processes and procedures associated with border checks, which take place at authorised crossing points, including airports, and border surveillance, which is carried out on the so-called green (land) borders between authorised crossing points and along the blue (sea) borders. This definition is largely the same as that given by Hills, who, however, does not include sea borders: A Hills, 'The Rationalities of European Border Security' (1996) 15 European Border Security 1, 69.
} 
of the external borders is already taking shape in the absence of ratification of the Lisbon Treaty. ${ }^{2}$

\section{Current treaty framework for the management of external borders}

It was not until the Treaty of Amsterdam that the Community acquired powers for the regulation of its external borders. This came about through the transfer of policies from the Third Pillar of the Treaty establishing the European Union (EU) to Title IV of the Treaty establishing the European Community (EC) and the transformation of the Schengen acquis into European law. Article 62(2)(a) EC confers upon the Council the power to adopt measures on the crossing of the external borders of the Member States, establishing standards and procedures to be followed by Member States in carrying out checks on persons at such borders. On the basis of Article $66 \mathrm{EC}$, the Council can take measures to ensure co-operation between the relevant departments of the administrations of Member States in the areas covered by Title IV EC, and also between these departments and the Commission. ${ }^{3}$

The transfer of powers in JHA to the First Pillar has been both partial and gradual. Article 67 EC provided for a transitional period of five years in which the Commission shared its right of initiative with Member States. This period ended on 1 May 2004, although the Commission remains obliged to take into account Member States' requests to submit proposals to the Council. During the transitional period, decision-making in the Council was unanimous, with a right of consultation for the Parliament. On the basis of the second indent of Article 68(2) EC, the Council extended, as of 1 January 2005, the co-decision procedure to Article 62(2)(a) EC. ${ }^{4}$

Article 68 EC restricts the role of the European Court of Justice (ECJ) under Title IV EC. Only national courts from which no further judicial

2 The external relations of EU border management will be outside the scope of this paper, although it should be stressed that the external dimension of EU border management is becoming increasingly important. See, for instance, Commission (EC), 'Report on the evaluation and future development of the FRONTEX Agency' (Communication) COM (2008) 67 final, 13 February 2008, 8.

3 No agreement was reached on the legal basis for the Schengen Information System (SIS) and consequently it was brought under the Third Pillar on the basis of Article 2, paragraph 4 of the Schengen Protocol.

4 Council Decision 2004/927/EC providing for certain areas covered by Title IV of Part Three of the Treaty establishing the European Community to be governed by the procedure laid down in Article 251 of that Treaty [2004] OJ L396/45. In accordance with Protocol No 35 on Article 67 EC, the Council has acted since 1 May 2004 by qualified majority on a proposal from the Commission and after consulting the European Parliament in order to adopt the measures referred to in Article 66. 
remedy is possible have a duty to refer preliminary questions to the ECJ. In an area that touches directly upon the civil liberties of EU citizens, this is obviously a regrettable anomaly. Although Article 67(2), second indent, EC calls upon the Council to take a decision on the adaptation of the Court's powers after the transitional period, it has not done so. ${ }^{5}$

A further restriction of the Court's jurisdiction is contained in Article 68(2), excluding the Court's jurisdiction over measures taken under Article 62(1) EC (the legal basis for measures related to the abolition of internal border controls) in so far as they relate to the maintenance of law and order and the safeguarding of internal security. ${ }^{6}$ One could interpret this paragraph as the Community equivalent of Article 35(5) EU, which aims to prevent the Court from pronouncing itself on the legality and proportionality of Member States' law enforcement authorities. Peers, however, has argued it would not prevent the Court from ruling on the interpretation or validity of Community acts in a preliminary ruling procedure. ${ }^{7}$ Interestingly, its wording would also not prevent the Court from pronouncing itself on the correct interpretation of measures based on Article 62(2) or Article 66 EC relating to external borders. It would therefore be possible for the Court to rule for instance on the conformity of the actions of national border guard authorities, even if it may be assumed that the Member States intended to exclude these enforcement authorities from the scope of the Court's powers of review.

It is imperative to realise that due to the opt-out of the United Kingdom and Ireland, the external borders of the Schengen area do not coincide with the 'external borders' of the area in which there is free movement for persons having this right under Community law. Likewise, the external borders of the Schengen area, because of the association with the Schengen acquis of Norway, Iceland, Switzerland and Liechtenstein, as well as the exclusion of the non-European territories of the Schengen Member States, do not coincide with the external borders of the EU.

It is the Schengen external borders, as initially defined in Article 1 of the Schengen Implementing Convention (CISA) that form the object of

\footnotetext{
5 In 2006, the Commission did publish a Communication in which it proposed to cease application of Article 68, but the Council has never taken any decision to that effect: Commission (EC), 'Adaptation of the provisions of Title IV of the Treaty establishing the European Community relating to the jurisdiction of the Court of Justice with a view to ensuring more effective judicial protection' (Communication) COM (2006) 346 final, 28 June 2006.

6 A similar exception is contained in the Schengen Protocol art 2(1).

7 S Peers, EU Justice and Home Affairs (Harlow, Longman 2000) 47. Case C-150/05 Jean Leon Van Straaten v Staat der Nederlanden and Republiek Italië [2006] ECR I-9327 seems to confirm this approach. In this case, the ECJ ruled on the correct interpretation of the CISA which lay at the basis of a SIS entry made by Italian enforcement authorities, giving the referring Dutch court the tools to order the removal of the entry.
} 
Community competence. Whilst at the Schengen external borders, border procedures are regulated by EC law, at the non-Schengen EU external borders it is the national law of the Member State in question that determines the procedure to be followed, albeit within the limits imposed by EU law. ${ }^{8}$ It is also important to point out that the Schengen external borders are defined by reference to the Member States' external borders. The new Article 69(4) FEU underlines once more that the powers currently contained in Article $62 \mathrm{EC}$ leave the competence of Member States unaffected as regards the geographical demarcation of their borders, in accordance with international law. ${ }^{9}$

\section{Legislation $v$ executive action}

The AFSJ is generally characterised by executive action and operational co-ordination as opposed to the "legislation-centred constitutional logic of the EU'. ${ }^{10}$ Bearing in mind the communitarisation of competences for the management of the external borders, this section will consider how far this qualification remains valid with respect to this policy. To what extent does Community action in this field remain distinct from that in other areas covered by the First Pillar?

In order to answer this question, one should distinguish between executive action which has effects in law, ie which creates enforceable rights and obligations for third parties, and executive action which does not. Implementation of legislation by the Commission, the Council or regulatory agencies with decision-making power would fall under the former. Technical and scientific assistance, as well as operational coordination, be it by the Commission, the Council or a regulatory agency, would be covered by the latter.

Walker in his discussion of the legislative/executive nature of the AFSJ opposes legislation to executive and operational action, without distinguishing between the latter two. ${ }^{11} \mathrm{He}$ argues that both refer to the "post-legislative (or in some cases non-legislation-based) phase of policy application and implementation.' On the one hand, 'executive' is used to

\footnotetext{
8 These limits concern the way in which EU citizens and their relatives with border crossing rights based on the EU's fundamental freedom of free movement are to be treated.

9 This was also stipulated in the $9^{\text {th }}$ recital to Decision 2004/927/EC (n 4). Of course, Member States will always be under the obligation to comply with EU law in exercising this competence. See in this respect, Case C-146/89 Commission v UK [1991] ECR I-3533 on the extension by the UK of its territorial sea and the effects thereof on the activities of fishermen from other Member States.

10 N Walker, 'In Search of the Area of Freedom, Security and Justice: A Constitutional Odyssey' in N Walker (ed), Europe's Area of Freedom, Security and Justice (Oxford University Press, Oxford 2004) 21-22.

11 Walker (n 10) 21-22.
} 
refer to 'high' governmental activity and 'operation' to 'low' bureaucratic or professional activity. ${ }^{12}$ In the discussion on the executive nature of the AFJS, one tends to underline the 'on the ground' or 'practical' nature of EU activity. In this context, however, the reference to 'executive' often carries with it the notion of law enforcement authorities' powers of coercion. ${ }^{13}$

As Hoffman has argued, the extent of the European administrative space can only be appreciated by looking beyond the administration's implementation activity. ${ }^{14}$ By defining the nature of EU executive action more precisely, the distinction proposed between executive action which has legal effect and that which does not allows us to do just that. Considering that the EU functions as a system of multi-level or network governance, including in the AFSJ, a distinction based on the legal effect of EU administrative activity is preferred over a distinction based on the level at which this executive action takes place. ${ }^{15}$

Since the expiry of the transitional period, legislation under Title IV EC now generally confers the power to take implementing measures on the Commission, under the supervision of a comitology committee. ${ }^{16}$ The ECJ has shown that it will closely scrutinise any retention of implementing powers by the Council. ${ }^{17}$ In relation to the more 'factual' EU activity implementing Community law, there is however an absence of a clear legal framework. This may prove particularly problematic in relation to operational co-ordination in the AFSJ, where the co-operation between Member States may involve the exercise of coercive powers against individuals.

\subsection{The building of a Schengen external borders acquis}

In the first few years following the entry into force of the Treaty of Amsterdam, there was relatively little legislative activity in the field of

\footnotetext{
12 Walker (n 10) 21-22.

13 Walker (n 10) 21-22.

14 H Hoffman, 'Mapping the European Administrative Space' (2008) 31 West European Politics 4, 665.

15 B Kohler-Koch and B Rittberger, 'Review Article: The "Governance Turn" in EU Studies' in U Sedelmeier and AR Young (eds), JCMS Annual Review of the European Union in 2005 (Blackwell, Oxford 2006) 27-49. See also K Eder and HJ Trenz, 'The Making of a European Public Space: The Case of Justice and Home Affairs' in B Kohler-Koch (ed), Linking EU and National Governance (Oxford University Press, Oxford 2003) 111-134.

16 See Article 202, third indent EC and Council Decision 1999/468/EC laying down the procedures for the exercise of implementing powers conferred on the Commission [1999] OJ L184/23, as amended by Council Decision 2006/512/EC [2006] OJ L200/11.

17 See the Court's ruling in Case C-133/06 European Parliament $v$ Council [2008] ECR-I 3189 , moving away from its more cautious approach in Case C-257/01 Commission v Council [2005] ECR I-345.
} 
external borders management. Regulations concerning local border traffic and common standards for the surveillance of land and sea borders envisaged in the 1999 Schengen Regulations Action Plan of the Council's Frontiers Working Party were not adopted until 2006. ${ }^{18}$

Of course, a considerable acquis was already in place in the form of those parts of the Schengen acquis that were incorporated into the EU legal order by the Treaty of Amsterdam and that were assigned to the new legal bases provided for by that Treaty. ${ }^{19}$ It was the impending enlargement, however, reinforced by the sharp increase in sub-Saharan migration across the Mediterranean from 2000 onwards and the events of 9/11 that brought borders back onto the EU's policy agenda. ${ }^{20}$ The December 2001 JHA Council meeting agreed on the following four points: 1) to strengthen and standardise European border controls 2) to assist candidate States in organising controls at Europe's future external borders by instituting operational co-operation 3) to facilitate crisis management with regard to border control and 4) to prevent illegal immigration and other forms of cross-border crime. ${ }^{21}$ Again without making any reference to possible legislative initiatives, the Laeken European Council Conclusions of 14 and 15 December 2001 asked the Council and the Commission to "work out arrangements for cooperation between services responsible for external border control and to examine the conditions in which a mechanism or common services to control external borders could be created. ${ }^{22}$

In response, the Commission came forward with its 2002 Communication on the integrated management of the external borders. In this communication, for the first time reference was made to the establishment of a 'common corpus of legislation' in relation to the management of the common Schengen borders. ${ }^{23}$ In the short term, the most important

18 Council Frontiers Working Party, 'Action Plan: Revisions of the Schengen border control regulations' Council Document 12479/99, 4 November 1999.

19 Council Decision 1999/435/EC concerning the definition of the Schengen acquis [1999] OJ L176/1 and Council Decision 1999/436/EC determining the legal basis for each of the provisions or decisions which constitute the Schengen acquis [1999] OJ L176/17.

20 J Monar, 'Justice and Home Affairs' in L Miles (ed), JCMS The European Union: Annual Review 2002/2003 (Oxford, Blackwell 2003) 124. See also H De Haas, 'The Myth of Invasion: Irregular Migration from West Africa to the Maghreb and the European Union' (IMI Research Report) (Oxford, October 2007) 15. Haas links this increase to a major anti-immigrant backlash in Libya in 2000.

${ }^{21}$ Results of the JHA Council Meeting, Brussels, 6-7 December 2001, Council Document $14581 / 01,13$.

22 Presidency Conclusions of the Laeken European Council, 14 and 15 December 2001, No 00300/1/01, point 42 .

${ }^{23}$ Commission (EC), 'Towards Integrated Management of the External Borders of the Member States of the European Union' (Communication) COM (2002) 233 final, 7 May 2002, 12 . 
measures envisaged remained the recasting of the Schengen acquis in a regulation (the Schengen Borders Code) and the long overdue adoption of measures on local border traffic. ${ }^{24}$

The Communication further stated that by having recourse to Article $66 \mathrm{EC}$, the Community budget should contribute to the financing of a common policy. A financial burden-sharing system should be established in the run-up to the creation of a complementary operational burden-sharing mechanism. The operational mechanism was to take the shape of a European Corps of Border Guards; a body endowed with a 'genuine operational inspection function', which it could exercise either at the request of a Member State or on its own initiative. ${ }^{25}$ The Council's Action Plan for the Management of the External Borders of the Member States largely adopted the Commission's proposals, but was understandably much more careful as regards the setting-up of a European Corps of Border Guards. ${ }^{26}$ It generally put much less emphasis on the eventual need for common legislation and financing, focusing instead on measures of an operational rather than legal nature giving the plan a very 'pragmatic' orientation. ${ }^{27}$

Notwithstanding this practical approach, a wide range of legislative measures has been adopted which determine, either directly or indirectly, the way in which the Schengen external borders are managed. These measures neither relate exclusively to the act of crossing an external border nor fully coincide with those envisaged in the Commission Communication or the Council's Action Plan. This is first of all because the Court has construed the notion of 'Schengen developing measures' broadly. The effect of this is that all measures that, judged by their content and purpose, render parts of the Schengen acquis more effective qualify as such. ${ }^{28}$ As a result, measures developing the Schengen acquis on external borders adopted on the basis of Article 62(2)(a) EC and Article 66 EC cover a broad range of legislative initiatives from the establishment of the EU's border agency Frontex to common requirements regarding EU passports. In addition, a considerable number of measures that find

\footnotetext{
24 Convention Implementing the Schengen Agreement (CISA) art 3.

25 Commission (EC) (n 23) 13.

26 Council, 'Plan for the management of the external borders of the Member States of the European Union' Council Document 10019/02, 14 June 2002, point 120. The plan was officially endorsed in the European Council Conclusions, Seville, 21-22 June 2002, point 27.

27 J Monar, 'The Project of a European Border Guard' in M Caparini and O Marenin (eds), Borders and Security Governance: Managing Borders in a Globalised World (LIT Verlag, Münster 2006) 200.

28 Case C-77/05 United Kingdom v Council [2007] ECR I-1 145 para 85 and Case C-137/05 United Kingdom v Council [2007] ECR I-11593 para 56.
} 
their legal basis in other areas of competence under Title IV EC (such as irregular migration, visa or asylum) or under the Third Pillar, include provisions which affect the way in which the Schengen external borders are managed. As such, the rules that make up the 'Schengen external borders acquis' are to be found across a broad range of measures, which can be roughly divided into five categories.

One may first identify the Schengen borders acquis in a narrow sense: the measures that establish the border crossing regime at the Schengen external borders The essence of EU activity in the area of border management is to ensure respect for and correct application of these measures. The most important piece of legislation in this category is, of course, the Schengen Borders Code (SBC). ${ }^{29}$ A second category of legislative measures consists of measures that aim to establish a degree of financial burden-sharing as regards the management of the Schengen external borders. Here the most important instrument is the External Borders Fund (EBF). ${ }^{30} \mathrm{~A}$ third category of measures relates to the establishment of centralised databases for the purpose of migration and border management: the Schengen Information System (SIS), the Visa Information System (VIS) and Eurodac. ${ }^{31}$ A fourth category is made up of measures that penalise illegal entry, smuggling and trafficking. ${ }^{32}$

The last category consists of institutional measures for the co-ordination of operational co-operation. Operational co-operation has been the cornerstone of the EU's policy for the management of external borders. Many of the measures in the previous categories enable or facilitate operational co-operation between border guard authorities through financial support or information exchange. The 2002 Commission Communication put a lot of emphasis on the concept of operational burden-sharing, pooling not only financial but also human and technical resources and pro-

29 Regulation (EC) No 562/2006 establishing a Community Code on the rules governing the movement of persons across borders (Schengen Borders Code) [2006] OJ L105/1.

30 Decision 574/2007/EC establishing the External Borders Fund for the period 2007 to 2013 as part of the General programme 'Solidarity and Management of Migration Flows' [2007] OJ L144/22.

31 Regulation (EC) No 1987/2006 and Council Decision 2007/533/JHA on the establishment, operation and use of the second generation Schengen Information System (SIS II) [2006] OJ L381/4 and [2007] OJ L205/63. These Regulations repeal all provisions from CISA regarding SIS, although SIS II has yet to become functional; Regulation (EC) No $767 / 2008$ concerning the Visa Information System (VIS) and the exchange of data between Member States on short-stay visas [2008] OJ L218/60; Council Regulation (EC) No $2725 / 2000$ concerning the establishment of 'Eurodac' for the comparison of fingerprints for the effective application of the Dublin Convention [2000] OJ L316/1.

32 See, for instance, Council Directive 2002/90/EC defining the facilitation of unauthorised entry, transit and residence [2002] OJ L328/17 and Framework Decision 2002/946/ JHA on the strengthening of the penal framework to prevent the facilitation of unauthorised entry, transit and residence [2002] OJ L328/1. 
posing the establishment of a European Corps of Border Guards. ${ }^{33}$ The Council's Action Plan on the External Borders had carefully concluded that 'institutional steps could be considered' which 'could include a possible decision on the setting up of a European Corps of Border Guards. ${ }^{34}$

The most important steps for operational co-operation at the external borders, if not from a legal point of view, then from a symbolic one, has been the adoption of Council Regulation (EC) No 2004/2007 establishing a Community agency for the coordination of operational cooperation at the external borders of the Member States (Frontex). ${ }^{35}$ This regulation was subsequently amended by Regulation (EC) No 863/2007. ${ }^{36}$ Both regulations are based on Articles 62(2)(a) and 66 EC. As the Court confirmed in Case C-77/05, the Frontex regulation constitutes a development of that part of the Schengen acquis in which the UK and Ireland do not participate, for which reason they have been excluded from the Agency. ${ }^{37}$ The Commission's proposal for an amendment of the Frontex Regulation added that the UK and Ireland were to be excluded, since the agency was to be regarded as a measure of solidarity applicable only to the countries participating in the Schengen acquis on external borders. ${ }^{38}$

The road to Warsaw, from where the Agency has been functioning since 2005, has been a winding one. ${ }^{39}$ The Council's Action plan focused on practical initiatives rather than legislative measures. Informed by an Italian-led feasibility study into the setting-up of a European Border Police, it advocated the establishment of a 'polycentric' network structure consisting of ad hoc centres specialised in different areas of border man-

33 Commission (EC) (n 23).

34 Council (n 26) point 120.

35 Article 64(2) EC; Council Regulation (EC) No 2007/2004 establishing a European Agency for the Management of Operational Cooperation at the External Borders of the Member States of the European Union [2004] OJ L349/1 art 8a.

36 Regulation (EC) No 863/2007 ('Rabit Regulation') establishing a mechanism for the creation of Rapid Border Intervention Teams and amending Council Regulation (EC) No $2007 / 2004$ as regards that mechanism and regulating the tasks and powers of guest officers [2007] OJ L199/30.

37 Case C-77/05 (n 28).

38 Commission (EC), 'Document accompanying the Proposal for a Regulation of the European Parliament and of the Council establishing a mechanism for the creation of Rapid Border Intervention Teams and amending Council Regulation (EC) No 2007/2004 as regards that mechanism' (Staff Working Document) SEC (2006) 953, 19 July 2006, 2-3. Here one could argue, however, that solidarity is a broader value underpinning Member States' co-operation in general, as expressed in Article 2 EC. Under the Lisbon Treaty, solidarity underpins all co-operation on asylum, immigration and external borders. See the Treaty on the Functioning of the European Union (TFEU) art 61(2).

39 Council Decision 2005/385/EC designating the seat of the European Agency for the Management of Operational Cooperation at the External Borders of the Member States of the European Union [2005] OJ L114/13. 
agement. ${ }^{40}$ It called for joint operations of national border guard agencies at the external borders and the creation of national contact points. The Council also followed the Commission's suggestion to set up a Common Unit of External Border practitioners falling under the Council's Strategic Committee on Immigration, Frontiers and Asylum (SCIFA).

The Common Unit (or SCIFA+) consisted of the members of SCIFA and the heads of Member State border control services. Its task was to oversee the development of a common policy on external borders and act as a co-ordinator for the network structure and the joint operations proposed in the Action Plan. It was explicitly mentioned that SCIFA+ did not encroach upon the Commission's powers in this field, stating that it would not involve legislative proposals or implementing measures in the meaning of Article 202 EC. ${ }^{41}$

Between July 2002 and March 2003, SCIFA+ approved a total of 17 different programmes, ad hoc centres, pilot projects and joint operations. ${ }^{42}$ The Council has always maintained that these constituted intergovernmental co-operation arrangements between Member States. Depending on how one defines the term 'measure' in Articles 62(2)(a) and 66 EC, one could argue that the Treaty does not directly confer upon the Council the competence to engage in such co-ordinating activities, but merely gives the Community legislator the power to adopt legislation for this purpose. ${ }^{43}$ This is because the EC Treaty lacks an equivalent of Article $36 \mathrm{EU}$ which establishes a Coordinating Committee (Committee Article Trente-Six, CATS) made up of senior Member State officials in JHA with specific co-ordinating tasks under the Third Pillar. The presidency's report on the implementation of the joint activities expressly referred to a lack of legal basis for the setting-up of ad hoc centres and the carryingout of common operations. ${ }^{44}$

The Presidency report further listed a number of concerns in relation to operational co-operation which ranged from the need for suitable planning, preparation and central operational co-ordination to a lack of

\footnotetext{
40 Monar (n 27) 196.

${ }^{41}$ Council (n 26) point 47.

42 Council, 'Progress report on the implementation of the Plan for the management of the external borders of the Member States of the European Union and the comprehensive plan to combat illegal immigration' Council Document 14708/02, 26 November 2002.
}

43 As Monar has noted, this study was 'shaped by the input of national experts, who tended to defend national methods and organizational structures' (n 27) 196. See for a critical analysis: Statewatch, 'Cover-up! Proposed Regulation on European Border Guard hides unaccountable, operational bodies' <http://www.statewatch.org/news/2003/nov/EUborderpolice.pdf> last accessed 15 April 2009.

44 Council, 'Report on the implementation of programmes, ad hoc centres, pilot projects and joint operations' Council Document 10058/1/03, 11 June 2003, 9-10. 
adequate evaluation. ${ }^{45}$ The Commission Communication in view of the Thessaloniki European Council noted that the limitations of SCIFA+ as a working party had been demonstrated. ${ }^{46}$ These limitations related to its large membership and wide agenda, but presumably also to its lack of a common approach. ${ }^{47}$ The Commission therefore argued that while 'certain more strategic co-ordination tasks could remain with SCIFA+, the more operational tasks could be entrusted to a new permanent Community Structure'. ${ }^{48}$ This became the Practitioners' Common Unit (PUC), replacing SCIFA+ and consisting only of the heads of Member State border guard services. SCIFA remained responsible for the general strategy to set up an integrated border management system, while the PUC was to deal exclusively with operational issues. ${ }^{49}$

Throughout the summer of 2003, irregular landings on the EU's southern maritime borders continued to make headlines. ${ }^{50}$ The Thessaloniki European Council emphasised the importance of determining a more structured framework and the necessity of creating new institutional frameworks to enhance operational co-operation for the management of the external borders. ${ }^{51}$ The Commission, from the outset a proponent of more centralised co-operation, seized the opportunity and proposed the

45 Council (n 44) 9-10.

46 Commission (EC), 'Commission Communication in view of the European Council of Thessaloniki on the development of a common policy on illegal immigration, smuggling and trafficking of human beings, external borders and the return of illegal residents' (Communication) COM (2003) 323 final, 3 June 2003, 7.

47 House of Lords Select Committee on the EU, Proposals for a European Border Guard, HL (2002-3) (London, 29 $9^{\text {th }}$ Report of Session 2002-03, 1 July 2003) 14. In informal discussions, a Council official mentioned that each Member State was keen on having its own project. A Commission official from DG JLS rather cynically remarked that the ad hoc centres were more occupied with the design of their logo than anything else. See also the anonymous Commission official quoted in A Neal, 'Securitization and Risk at the EU Border: The Origins of FRONTEX' (2009) 47 Journal of Common Market Studies 2, 342.

48 Commission (EC) (n 46) 7-8.

49 Council Conclusions (JAI), Luxembourg 5-6 June 2003 (Council Document 9845/03). The political role of SCIFA was also underlined by the Finnish Presidency of 2006, which envisaged SCIFA taking the lead in the implementation of integrated Border Management. Presidency note for the Informal JHA Ministerial Meeting, Tampere, 20-22 September 2006, 2 <http://www.eu2006.fi/news_and_documents/other_documents/vko36/en_ GB/1157615375954/> last accessed 15 April 2009.

50 Even if in a Member State like Italy numbers were actually declining throughout 2003, the phenomenon continued to be of great concern to the Member States involved. L Coslovi, 'Brevi note sull'immigrazione via mare in Italia e in Spagna' (CeSPI, Rome January 2007). See also the Council's Programme of measures to combat illegal immigration across the maritime borders of the European Union, a clear example of the Council's executive role in operational co-ordination of the management of external borders (Council Document 13791/03).

51 European Council Conclusions, Thessaloniki, 19-20 June 2003, points 12 and 14. 
creation of Frontex. ${ }^{52}$ The Commission's intention of coming forward with this proposal had already been welcomed by the European Council. ${ }^{53}$ The regulation was adopted in October 2004 after another summer witnessing the arrival of irregular migrants by sea.

The establishment of Frontex shows how the co-ordination of operational co-operation, not unlike the competences in border management themselves, has gradually been communitarised. If one is willing to accept that the co-ordinating activities of SCIFA+/PUC constituted purely intergovernmental arrangements, the case of Frontex confirms that in the case of delegation to agencies, powers are often transferred vertically (from the national to the EU level) rather than horizontally (from Community institutions to specialised agencies). ${ }^{54}$

If one is to consider the co-ordinating activities of SCIFA+/PUC as Community actions, it becomes clear that with the transfer of operational co-ordination from the PUC to Frontex, there has nevertheless been a shift from a Member-State driven co-ordination within the Council to the more supranational approach of a Community agency. Simultaneously, this shift has empowered the Commission because of its influence on the agency. ${ }^{55}$ It could even be argued that the Commission, rather than SCIFA, is increasingly taking responsibility for more strategic co-ordination tasks, mapping out the general strategy for the integrated management of the external borders. ${ }^{56}$

\subsection{Operational co-ordination and co-operation}

A common corpus of legislation was only one of a number of elements which the Commission identified in its 2002 Communication as central to a policy for the management of external borders. The other components were of a much more practical nature and included the establishment of

52 Commission (EC), 'Proposal for a Council Regulation establishing a European Agency for the Management of Operational Co-operation at the External Borders' COM (2003) 687 final, 20 November 2003.

53 European Council Conclusions, Brussels, 16-17 October 2003, under III.

54 R Dehousse, 'Misfits: EU Law and the misfits of European Governance' (2002) Jean Monnet Working Paper 2 (New York), 12. See also the Rapporteur of the European Parliament, 'Report on the proposal for a Council regulation establishing a European Agency for the Management of Operational Co-operation at the External Borders' (A5-0093/2004), tabled 24 February 2004.

55 See E Busuioc, 'Autonomy, accountability and control - the case of European agencies' $4^{\text {th }}$ ECPR General Conference, Pisa, 5-8 September 2007, 17-18.

56 See, for instance, Commission (EC), 'Reinforcing the Management of the European Union's Southern Maritime Borders' (Communication) COM (2006) 733 final, 30 November 2006 and the Council Conclusions on this Communication (Council Document 13231/06). The Commission will of course require the endorsement of the Council for such co-ordinating activities. 
common co-ordination and operational co-operation mechanisms, common integrated risk analysis and the training of staff in a European dimension. ${ }^{57}$ Indeed, the Council's Action Plan for the Management of the External Borders and the implementation thereof was characterised by the 'absolute prominence of the operational dimension. ${ }^{58}$

One can clearly see the origins of such an operational approach in the Commission's 1988 Communication on the abolition of controls of persons at intra-Community borders. In relation to the question at which level 'flanking measures' necessary to achieve the free movement of persons should be taken, the Commission stated that it was

fully aware of the delicate nature and exercise of this kind, and it considers that attention should be focused on practical effectiveness rather than on matters of legal doctrine. Therefore ... the Commission proposes that Community legislation in this field be applied only to those cases where the legal security and uniformity provided by Community law constitutes the best instrument to achieve the desired goal. ${ }^{59}$

This means that all other action was to be left to intergovernmental co-operation. Of course, the approach advocated here can be explained by the lack of competence at the time to proceed with Community legislation. At the same time, however, it underlines the importance of Member States' sovereignty concerns and the emphasis on 'practical effectiveness' in response thereto. The Communication continued by stating that there would be a 'large scope left to cooperation among Member States.' That this co-operation took place more on the basis of ad hoc informal contacts between administrations, rather than within an international treaty framework is evidenced by the host of informal, secretive bodies that developed in the field of JHA from the mid-1980s. ${ }^{60}$

Schengen co-operation formed an exception to the extent that it was based on a legal framework, albeit an intergovernmental one. However, as Guiraudon has pointed out, this framework was never meant to create a 'constraining set of rules with monitoring mechanisms', but much

\footnotetext{
57 Commission (EC) (n 23) 12.

58 F Pastore, 'Visa, Borders, Immigration: Formation, Structure and Current Evolution of the EU Entry Control System' in N Walker (ed), Europe's Area of Freedom, Security and Justice (Oxford University Press, Oxford 2004) 124.

59 Commission (EC), 'Commission Communication on the abolition of controls of persons at intra-Community borders' (Communication) COM (88) 640 final, 7 December 1988, 6-7.

60 See S Lavenex and W Wallace, 'Justice and Home Affairs - Towards a "European Public Order?"' in H Wallace and W Wallace (eds), Policy Making in the European Union (Oxford University Press, Oxford 2005) 459.
} 
rather to escape such legal control and constraints at the national level. ${ }^{61}$ In respect of the communitarised parts of the AFSJ, this was remedied by the Treaty of Amsterdam.

Walker has observed that Member States' sovereignty concerns are more likely to be triggered by 'familiar and more symbolically loaded legislation centred indices of national authority' than by other forms of policy co-operation. ${ }^{62}$ As far as the management of the external borders is concerned, this seems to remain valid under Title IV EC, as exemplified by the history of Frontex's establishment and the continuing resistance of some Member States to a more centralised model of border agency ${ }^{63}$

Fostering European integration in the AFSJ by focusing on the 'mere technical' co-operation between Member States' competent authorities is, however, problematic. It fails to acknowledge the highly political and value-laden nature of the competences that are grouped in this policy field, or rather it acknowledges this highly political nature by masking it as non-political. Of course, 'any decision about whether something is unpolitical is always a political decision'. ${ }^{64}$ However, the co-ordination of operational co-operation in the AFSJ should not be allowed to substitute policy and lawmaking processes as defined in the EU Treaties and according to which the future direction of the European project in a given area would normally be determined.

In addition, it would be wrong to consider the co-ordination of operational co-operation itself as value-neutral or merely 'technical'. The Council itself notes that intelligence-led law enforcement includes the setting of political priorities. ${ }^{65}$ The question should be asked to what extent this should be the task of unaccountable working groups or non-majoritarian bodies. Since operational co-ordination does not entail the introduction of legally binding acts, it escapes not only democratic but also judicial scrutiny. The more general concern that regulatory agencies 'might stray into areas more properly the domain of the policy-making branches of the EU' is equally valid in relation to those agencies that have the task of co-ordinating operational activity. ${ }^{66}$

\footnotetext{
${ }^{61}$ V Guiraudon, 'The EU "garbage can": Accounting for policy developments in the immigration domain' Conference of the European Community Studies Association, Madison, 29 May-1 June 2001, 13.

62 Walker (n 10) 22.

63 These sensitivities may be particularly strong for some of the EU10 Member States, who only regained their full national sovereignty at the end of the Cold War. Monar (n 27) 178.

${ }^{64}$ C Schmitt, Political Theology: Four Chapters on the Concept of Sovereignty (University of Chicago Press, Chicago 1985) 2.

65 Council, Architecture of Internal Security, Document 9596/1/06 REV1, 22 May 2006, 3.

66 Commission (EC), 'Commission Communication on European Agencies - The way forward' (Communication) COM (2008) 135 final, 11 March 2008, 6.
} 
Lastly, Member States may fail to appreciate the extent to which operational co-operation may "penetrate national systems and challenge statist prerogatives. ${ }^{67}$ This may relate to both the organisation of Member States' law enforcement agencies, as well as the way in which they operate. In the field of management of the external borders, clear examples of both can be found in the Commission Communication on the setting-up of a European Border Surveillance System (EUROSUR). ${ }^{68}$ First, it 'invites' Member States to set up 'one single co-ordination centre'. ${ }^{69}$ Second, it refers to the establishment of a group of experts that should draw up guidelines for the tasks of and co-operation between these national coordination centres. ${ }^{70}$

The Court has never explicitly recognised a principle of institutional autonomy as such, but it has held in relation to Member States' implementing powers that in the absence of Community legislation it is up to each state's constitutional system how these powers are exercised and to which specific national bodies they are entrusted. ${ }^{71}$ One may wonder if Community legislation could fully pre-empt Member States' powers. Article 4(2) TEU states that the Union shall respect Member States' national identities, inherent in their fundamental structures, political and constitutional, inclusive of regional and local self-government, and state functions, including safeguarding national security. This seems to suggest that the institutional autonomy of the Member States constitutes a more fundamental value. ${ }^{72}$ An example of how respect for this principle may be ensured in legislation can be found in the EBF. This decision allows Member States to designate several certifying and audit authorities or delegated authorities for the implementation of the money provided by the fund, on the condition that there is 'a clear allocation of functions for each of these authorities. ${ }^{73}$ While it seems nevertheless obvious that

\footnotetext{
67 Walker (n 10) 22.

68 Commission (EC), 'Commission Communication examining the creation of a European Border Surveillance System (EUROSUR)' (Communication) COM (2008) 68 final, 13 February 2008.

69 Currently, about 50 authorities from over 30 institutions have responsibilities in the surveillance of the southern external maritime borders. Commission (EC) (n 68) 6.

70 Commission (EC) (n 68) 7.

71 Joined Cases 51-54/71 International Fruit Company NV and others v Produktschap voor Groenten en Fruit [1971] ECR 1107 para 4.

72 Barbier-Le Bris considers the institutional autonomy of the Member States to be a principle of Community law. She has argued, with reference to the equivalent of this article in the Constitutional Treaty, that Community legislation cannot make the principle fully devoid of its content: M Barbier-Le Bris, 'Les Principes d'autonomie institutionelle et procédurale et de coopération loyale. Les Etats membres de l'Union européenne, des Etats pas comme les autres' in Le Droit de l'Union en principes - Liber Amicorum en l'honneur de Jean Raux (Editions Apogée, Rennes 2006) 451-452
}

73 Recital 25, Decision 574/2007/EC (n 30). See also Articles 12 and 27 of the Decision. 
legislation can at least limit Member States' institutional autonomy, the question is to what extent operational co-operation should be allowed to do the same. ${ }^{74}$

One of the characteristics of the different forms of operational co-ordination that have emerged under the AFSJ is that they originate in practical co-operation arrangements between the law enforcement agencies of a number of individual Member States. Monar has argued that these 'common, rather informal structures, play an important role as points of encounter and information exchange between officials from different Member States, especially after enlargement. ${ }^{75}$

It would seem logical to assume that legislation on operational cooperation forms the codification of bottom-up developments. Very often, however, on-the-ground co-operation originates in and is co-ordinated by Council working groups, which consist of senior law enforcement staff of the Member States. ${ }^{76}$ Curtin has in this respect highlighted the evolving autonomous executive role of the Council and other non-majoritarian bodies alongside the Commission. ${ }^{77}$ At the same time, in the area of external borders management, there is an increasingly important role for the Commission as policy initiator and Frontex as co-ordinator of operational activities. The JHA agencies have recently emphasised the importance of being heard in the legislative process. ${ }^{78}$ This would ensure that where amendments are made to their structure or tasks, account is taken of their specific needs and experience. Although agencies are, of course, important stakeholders in the legislative process, care should be taken that they are not allowed to dictate it, thereby setting their own rules and potentially pursuing their own agendas rather than the general interest.

\footnotetext{
74 In addition to the more principled argument made above in relation to the nature of competences in the AFSJ, further arguments can be made similar to those advanced by Hatzopoulos in relation to the Open Method of Co-ordination: V Hatzopoulos, 'Why the Open Method of Coordination Is Bad For You: A Letter to the EU' (2007) 13 European Law Journal 3, 316 ff. See also the European Parliament Resolution on institutional and legal implications of the use of 'soft law' instruments of 28 June 2007 (A6-0259/2007).

75 J Monar, 'Justice and Home Affairs after the 2004 Enlargement' (2003) 38 International Spectator 1, 16.

76 See H Aden, 'Administrative Governance in the field of EU Police and Judicial Cooperation' in Hofmann and Türk (eds), EU Administrative Governance (Edward Elgar, Cheltenham 2006) 351. This is true as much for the Third Pillar as it is for the field of external borders management under the First.

77 D Curtin, 'European Union Executive Actors Evolving in the Shade?' in J De Zwaan, J Jans and F Nelissen (eds), The European Union - an Ongoing Process of Integration, Liber Amicorum A. Kellerman (TMC Asser Press, The Hague 2004) 99-101.

78 Summary of discussions of the meeting of the JHA Agencies (18 June 2008), Council Document 11644/08, 9 July 2008, 2.
} 
Operational co-operation is generally given a legal basis once a certain level of trust has been achieved and there is the need to remedy the shortcomings of a more intergovernmental approach, linked to concerns about transparency and accountability, but also compliance and co-ordination. Frontex forms a point in case in this respect. The Council in its more recent Draft Conclusions on the principle of convergence and the architecture for internal security, seems to show for the first time a greater sensitivity to the need for a legislative dimension to operational co-operation in JHA. It not only calls for closer co-operation between personnel and the harmonisation of equipment and practice, but also for the harmonisation of legal frameworks, including the establishment of common legislative instruments "where these represent added value for the Member States. ${ }^{79}$ In the case of EUROSUR, however, future legislation is likely to confirm rather than shape its development, considering that important steps have already been taken under the heading of operational co-ordination. This is to be regretted, since projects of such importance, not least financially, deserve a proper legislative iter guaranteeing accountability and legitimacy.

It should be recalled that even where legislation is adopted for the purpose of fostering operational co-operation, this does not detract from the intrinsically operational nature of law enforcement tasks themselves. For this reason, the operational dimension of the AFSJ will remain a prominent feature under Title IV EC as far as the management of the external borders is concerned.

Operational co-operation in the AFSJ has the specific characteristic that it focuses on compliance with national rules and regulations rather than Community legislation. This is particularly so under the Third Pillar. However, even when operational co-operation aims to ensure compliance with Community legislation, such as the SBC, it does not of itself create rights and obligations for third parties. An example here is a joint patrol carrying out border surveillance in the context of a Frontex joint operation attempting to prevent irregular border crossings.

It should be stressed that in the AFSJ neither the Commission staff nor the staff of any of the agencies, be it under the First or Third Pillar, are endowed with autonomous law enforcement powers, let alone powers of coercion. In reality, operational activity at the EU level is therefore limited to the co-ordination of operational activities of national law enforcement agencies by EU bodies and institutions. Article 66 EC clearly refers to the co-operation in the areas covered by Title IV EC as being between the relevant departments of the administrations of the Member States. Like-

79 Council, 'Draft conclusions on the principle of convergence and the architecture for internal security' Council Document 13459/08, 24 September 2008, 3-4. 
wise, Article 30(1)(a) EU provides that police co-operation shall include operational co-operation between competent authorities. Neither does co-ordination at EU level replace bi- or multilateral initiatives between Member States themselves. This is underlined in the Frontex Regulation in Article 2(2), as well as in Article 16(3) of the SBC. The Lisbon Treaty would include a provision to this effect in Article 73 TFEU.

The Court has long held that 'only measures, the legal effects of which are binding on, and capable of affecting the interests of, the applicant by bringing about a distinct change in his legal position may be the subject of an application for annulment. ${ }^{80}$ The fact that the co-ordination of operational activities does not entail the taking of such measures, means these activities escape review by the EJC. ${ }^{81}$ The extension of the Court's jurisdiction in the Lisbon Treaty to review the acts of bodies, offices and agencies of the Union would not change this. ${ }^{82}$

The non-binding nature of operational activities vis-à-vis third parties does not mean that in the course of such activities rights and obligations cannot arise. For instance, if during a joint patrol a police officer arrests a suspected criminal or a border guard denies a third country national access to EU territory, this of course has effects in law. In the first case, however, the decision is taken on the basis of national law. In the second case, it is taken on the basis of the SBC, but by law enforcement personnel endowed with public authority on the basis of national law. ${ }^{83}$ Here it should, however, be noted that border guards from one Member State that participate in a joint operation/the deployment of a Rapid Border Intervention Team in another Member State may use force in accordance with the rules and regulations of the guest Member State. ${ }^{84}$

Importantly, operational activity could constitute a tort or criminal offence under Member States' domestic law. Here one could think of the (accidental) sinking of migrant boats or the shooting of irregular border cross-

\footnotetext{
80 Case 60/81 IBM $v$ Commission [1981] ECR 2639 para 9.

81 See the preparatory work done by the European Medicines Agency (EMEA), an EC body in the field of pharmaceuticals regulation: Case T-326/99 Nancy Fern Olivieri $v$ Commission and EMEA [2003] ECR II-6053 para 53.

82 TFEU art 263. A possible exception would be that a Member State could in theory challenge an operational plan which established the modus operandi for a joint operation as a decision. The Treaty amendment aimed, however, to provide a legal basis for the possibility of appealing against decisions made by regulatory agencies with decision-making powers (such as, for instance, the Office for Harmonisation in the Internal Market - Trademarks and Designs).

83 Under Article 13(2) SBC (n 29) and Council Regulation (EC) No 2007/2004 (n 35) Article $10(10)$, only national border guards can take the decision to refuse entry.

84 Council Regulation (EC) No 2007/2004 (n 35) art 10(6); Regulation (EC) No 863/2007 (n 36) art 6(6).
} 
ers. This possibility is recognised in the RABIT Regulation which for the purpose of civil and criminal liability equates visiting border guards with national border guards. ${ }^{85} \mathrm{~A}$ wrongful act that would be directly imputable to the co-ordinating activities of the EU could result in the non-contractual liability of the EU on the basis of Article 288(2) EC. This non-contractual liability extends beyond the institutions to other Community bodies established by the treaties. Community legislation often specifically provides for non-contractual liability in similar terms to those of Article 288(2) EC, for instance in the founding regulations of many EC agencies. ${ }^{86}$

Under the International Principles of State Liability, Member States could be held responsible for fatalities that are a direct result of specific border control measures. ${ }^{87}$ A parallel responsibility of the EU, under the Principles of the Responsibility of International Organisations, could be assumed where these measures are a direct result of the EU's co-ordinating activities. ${ }^{88}$ Member States could furthermore be held responsible for violations of human rights in the course of operational activities under the European Convention on Human Rights.

The approach taken above regarding the possible responsibility of the EU for its co-ordinating activities is of course theoretical. For instance, in the case of wrongdoings by Member States' border guards in the course of Frontex co-ordinated operational activities, it would be very difficult to actually attribute responsibility to the EU. However, it may be argued that whenever the EU acts as a co-ordinator of operational activity, it has a positive obligation to ensure that all participating Member States fully respect fundamental rights, such as the right to life. This is all the more so, bearing in mind that respect for these rights is one of the Union's foundational values listed in Article $6 \mathrm{EU}$, one of the Copenhagen criteria for accession and a condition in the Union's external relations with Third Countries. ${ }^{89}$

One could argue that the ECJ should have the right to review Member States' operational activities during joint operations. Of course, the limitation of jurisdiction in Article 68(2) EC and Article 35(5) EU could be

85 Council Regulation (EC) No 2007/2004 (n 35) arts 10b and 10c; Regulation (EC) No 863/2007 (n 36) arts 10 and 11.

86 See for instance, Council Regulation 2007/2004 (n 35) art 19(3).

87 See T Spijkerboer, 'The Human Cost of Border Control' (2007) 9 European Journal of Migration and Law 1, 137. ILC Draft Articles on responsibility of States for internationally wrongful acts, ICL Report of $53^{\text {rd }}$ Session, A/56/10, 2001, ch IV.

88 ILC Draft Articles on international responsibility of international organisations, ILC Report of $56^{\text {th }}$ Session, A/59/10, 2004, ch V.

89 As evidenced by the systematic inclusion since 1992 of a clause in its agreements with third countries defining respect for democratic principles and human rights clauses as an 'essential element'. 
used as an argument against the Court exercising jurisdiction over the operations of Member States' border guards, leaving the responsibility therefore with the Member States' courts and eventually the European Court of Human Rights. However, if one applies by analogy the Court's established case law in relation to Member States' national rules to Member States' operational activities, these latter would have to be compatible with fundamental rights as an obligation of Community law as soon as they fell within the scope of Community law. This would be the case for the management of the external borders. ${ }^{90}$ More cautiously, one could argue that the Court should assume jurisdiction when there are indications of 'serious and persistent violations, which highlight a problem of a systematic nature in the protection of fundamental rights in the Member States', since such situations could effectively undermine the EU's policy for the management of the external borders. ${ }^{91}$

\section{Innovations brought about by the Lisbon Treaty}

In what respect does the Lisbon Treaty change the legal framework outlined in the previous section? Most importantly, of course, the Lisbon Treaty will merge the First and Third Pillars, making co-decision the standard legislative procedure for the whole AFSJ and as such completing the process of communitarisation of competences in JHA. Under the Constitutional Treaty, the ECJ would have immediately been given full jurisdiction over this whole policy area. The Lisbon Treaty delays this for a maximum of five years for those policy areas that currently fall under the Third Pillar. In addition, the special protocols on the position of the UK, Ireland and Denmark are now extended to cover the whole of the AFSJ. ${ }^{92}$ The possibility for the Court to review the legality and proportionality of operations carried out by a Member State's police or other law enforcement agencies or of the exercising of a Member State's duty to maintain law and order and safeguard internal security remains excluded in Article 276 FEU. However, it would apply only to the chapters on judicial co-operation in criminal matters and police co-operation.

90 Case C-260/89 Elliniki Radiophonia Tiléorassi AE and Panellinia Omospondia Syllogon Prossopikou v Dimotiki Etairia Pliroforissis and Sotirios Kouvelas and Nicolaos Avdellas and others ('ERT') ECR-I 2925 para 42.

91 Opinion of 12 September 2007 of Advocate General Poiares Maduro in Case C-380/05 Centro Europa $7 \mathrm{Srl} v$ Ministero delle Comunicazioni e Autorità per le garanzie nelle comunicazioni and Direzione generale per le concessioni e le autorizzazioni del Ministero delle Comunicazioni ECR-I 349 para 22.

92 Under the transitional arrangements, the UK may, at the latest six months before the expiry of the transitional period, notify the Council it will not accept the powers of the institutions for measures falling under the old Third Pillar, which will then cease to apply to the UK, after which the UK may, however, decide to opt in again with regard to these measures under the Protocols applicable to the UK in the Schengen acquis and Title IV FEC. 
In the first chapter of Title V TFEU, the general provisions applicable to the AFSJ as a whole, the link between the absence of internal border controls and the policy on the external borders is much less prominent in Article 67(2) TFEU than under Article 61(a) EC, attributing a more independent importance to each. Article 67(3) TFEU states that the Union shall strive for a 'a high level of security' through 'co-ordination and cooperation between police and judicial authorities and other competent authorities'.

The current Title IV EC is only amended to a very limited extent and is clearly recognisable as such in Chapter 2 of Title V TFEU. Article 74 TFEU almost literally repeats the formulation of Article $66 \mathrm{EC}$ on administrative co-operation. The legal basis for measures on the external borders is, however, refined. Article 77(2)(b) refers to measures 'concerning the checks to which persons crossing external borders are subject', while Article $77(2)(d)$ provides that the Union has competence to take 'any measure necessary for the gradual establishment of an integrated management system for external borders.'

It is interesting that the Treaty introduces the concept of an integrated management system for external borders. This notion has so far been defined only in the December 2006 JHA Council Conclusions and is, moreover, a very broad concept, including not only border control, but also inter-agency co-operation and the fight against crime. ${ }^{93}$ It remains to be seen how far Article 77(2)(d) TFEU will allow for a move away from the exclusive focus on the movement of persons in respect of the crossing of the external borders. On the one hand, it could be argued that the article is sufficiently broadly formulated to serve as the legal basis, for instance, to extend Frontex's competences to the field of police co-operation. ${ }^{94}$ On the other hand, one might insist that this should be done under the chapter on police co-operation. Let us now consider how the Lisbon Treaty will affect executive action in general and operational co-ordination in the AFSJ in particular. One of the major innovations of the Constitutional Treaty was the introduction of a hierarchy of acts, explicitly distinguishing for the first time between legislative and executive measures or rather 'legislative and non-legislative acts'. This distinction has been maintained by the Lisbon Treaty. Article 289(3) TFEU defines as legislative acts, all legal acts that are adopted under legislative procedure. ${ }^{95}$

\footnotetext{
93 JHA Council Conclusions, 4-5 December 2006, 15801/06 (Presse 341) 26.

94 EU Counter-Terrorism Co-ordinator De Kerchove has called it 'absurd' that under the current legal framework Frontex cannot deal with security related threats other than irregular migration: B Bulcke, 'Europe is kwetsbaar voor Terrorisme', De Standaard Online, 11 September 2008 <http://www.standaard.be/Artikel/Detail.aspx?artikelId=5h20a73f > last accessed 15 April 2008.

95 Legislative procedure as such is not defined in the TFEU. From Articles 289(1) and (2) it follows, however, that it covers the adoption of a Regulation, Directive or Decision under
} 
There are two types of non-legislative act. First, Article 290(1) TFEU provides that the legislator can by legislative act delegate to the Commission the power to adopt non-legislative acts of general application to supplement or amend certain non-essential elements of a legislative act, so-called delegated acts. Second, under Article 291(1) 'where uniform conditions for implementing legally binding Union acts are needed', these acts shall confer on the Commission the power to adopt implementing acts.

The Convention Working Group on Simplification 'broached the idea' of introducing in the Constitutional Treaty the possibility of assigning the task of adopting certain implementing acts to decentralised agencies (or 'regulatory authorities') ${ }^{96}$ Neither the Constitutional Treaty nor the Lisbon Treaty, however, make any reference to the execution of Union legislation by agencies, effectively ignoring an important institutional reality in the EU. A sound legal basis in the Treaty for the delegation of powers to these agencies is still lacking. Curtin has rightly remarked that the Constitutional Treaty fell short of 'constitutionalising' a framework for the administration of the Union as a whole. This observation applies equally to the Lisbon Treaty, not only in respect of delegated and implementing powers, but also operational activity. ${ }^{97}$

While the Convention's Working Group on Simplification examined the distinction between legislative and non-legislative acts, the Working Group on the AFSJ grappled with the question of how to better separate the legislative and operational tasks of the Council. ${ }^{98}$ The Working Group did not, however, attempt to define either of the two concepts. The legislative tasks of the Council appear to have included the implementation of legislation as well. ${ }^{99}$ This definition would seem to be based on substantive rather than formal criteria, namely the legal effect vis-à-vis third parties.

ordinary legislative procedure (the current co-decision laid down in Article $290 \mathrm{TFEU}$ ) or special legislative procedure (limiting the role of either the Parliament or the Council to 'participation', the particular modalities of which are to be found in the respective legal bases throughout the Treaty). Note that the definition of legislative acts is a formal one.

96 European Convention Working Group IX on Simplification, Final Report ('Amato Report'), CONV 424/02, 29 November 2002, 12.

97 D Curtin, 'Mind the Gap: The Evolving EU Executive and the Constitution', Walter van Gerven Lecture 3 (Europa Law Publishing, Groningen 2004) 7.

98 European Convention Working Group X on Freedom, Security and Justice, Final Report, CONV 426/02, 2 December 2002, 3.

99 House of Lords Select Committee on the European Union, 'The Future of Europe: Constitutional Treaty - Draft Article 31 and Draft Articles from Part 2 (Freedom, Security and Justice)' HL (London, 16 ${ }^{\text {th }}$ Report of Session 2002-2003, 27 March 2003) 16. 
The Working Group proposed a merging of the various Council working groups dealing with internal security and removing CATS from the legislative process, limiting its role to sole co-ordinator of operational cooperation. ${ }^{100}$ Article 68 TFEU now states that the European Council shall define the strategic guidelines for legislative and operational planning within the area of freedom, security and justice. Article 71 TFEU provides for the setting-up of a Standing Committee on Internal Security (COSI), replacing CATS, which should 'ensure that operational cooperation on internal security is promoted and strengthened.' It should 'facilitate' the co-ordination of the activities of Member States' competent authorities. This seems to be a weaker formulation than if the article had stated it could co-ordinate activities itself. COSI's functioning would be without prejudice to the powers of COREPER. Representatives of relevant Union bodies, offices and agencies could be involved in its proceedings and both the European Parliament and national parliaments would have to be kept informed.

COSI has been criticised by some as an EU interior ministry in the making, ${ }^{101}$ by others as a toothless standing committee, ${ }^{102}$ and again others have asked whether it is necessary at all to formally provide for such a committee. ${ }^{103}$ Considering its potentially important role in the JHA, the mentioning of COSI in the Treaty seems justified. Bearing in mind that the EU is a system of attributed competences, it is difficult to see under which other legal basis the operational activities of the Council could find their foundation. In this respect, the article on COSI lacks precision and it will largely be left to the Council to decide on the exact definition of its tasks and composition.

In a Council Document mapping the preparatory work for COSI, internal security was broadly defined as encompassing both crime prevention and control, and anti-terrorism, but also the provision of an integrated management system for external borders as a major factor in prevent-

100 European Convention Working Group X (n 98) 16. See for an overview of the Council's working party structure: J Monar, 'Justice and Home Affairs' in G Edwards and G Wiessala (eds), JCMS The European Union 1999/2000: Annual Review of Activities (Blackwell, Oxford 2000) 137; M Den Boer and W Wallace, 'Justice and Home Affairs - Integration through Incrementalism?' in H Wallace and W Wallace (eds), Policy Making in the European Union (Oxford University Press, Oxford 2000) 515; Council, List of Council Preparatory Bodies, Council Document 11301/08, 17 July 2008.

101 T Bunyan, 'The Creation of an EU Interior Ministry' (Statewatch News, April 2003) 3 <http://www.statewatch.org/news/2003/apr/TBART.pdf> last accessed 15 April 2009.

102 A Townsend, 'Can the EU Deliver in the Area of Freedom, Security and Justice?' (2003) EPIN Working Paper No 9, Brussels, September 2003, 11.

103 J Monar, 'A new "Area of Freedom, Security and Justice" for the Enlarged EU? The results of the European Convention' in K Henderson, The Area of Freedom, Security and Justice in the Enlarged Europe (Palgrave MacMillan, Hampshire 2005) 127. 
ing (certain) forms of crime within the EU. ${ }^{104}$ Operational co-operation was defined as 'action related to concrete cases/events/crisis/phenomena, that require a trans-national approach, whereby all the concerned authorities of the Member States competent at national level for internal security issues collaborate with each other, i.e. bodies. ${ }^{105}$

It was however immediately emphasised that COSI would not be directly in charge of conducting operational activities. The document provided three different options in terms of tasks for the new Committee. The first would limit COSI's tasks to operational planning. The second would also include strategic functions, such as the drawing-up of an EU plan for internal security, evaluation and external relations. A final option, contrary to the history and wording of the article, would reintroduce a role in the legislative process. ${ }^{106}$ In any case, were legislative tasks to remain outside the Committee's remit, a separate committee could be made responsible for the co-ordination of all legislative work related to 'internal security'. This would imply that the four-level structure of lawmaking in the Council in the AFSJ will remain intact under the new Treaty. ${ }^{107}$

The composition of COSI would depend on the tasks given to it, but the Council has contemplated residential, permanent members. Representatives of EU bodies and agencies would only be present depending on the subject matter on the agenda. Interestingly, in the run-up to the establishment of COSI, the Hague Programme had called upon the Council to organise half-yearly meetings of the chairpersons of SCIFA and CATS, and representatives of the Commission, Europol, Eurojust, the European Border Agency (ie Frontex), the Police Chiefs' Task Force, and the Joint Situation Centre (SitCEN), thus giving a more permanent position to the agencies. ${ }^{108}$

When 'no' votes halted the ratification process of the Constitutional Treaty, the Council considered it inappropriate to continue setting up

\footnotetext{
104 Council, 'Discussion paper on the future Standing Committee on Internal Security (COSI) - Constitutional Treaty, art III-261' Council Document 6626/05, 21 February 2005, 2.

105 Council Document 6626/05 (n 104) 2.

106 The Commission had also expressed the view that ' $[\mathrm{t}]$ he COSI should not have legislative tasks': Council 'Strengthening security structuring operational police and judicial cooperation at European Union level (doc 16397/04 JAI 576 CATS 61) - Outcome of Article 36 Committee meeting of 17/18 January 2005' Council Document 5573/05, 21 January 2005.

107 Working group - CATS/SCIFA - Committee of Permanent Representatives (Coreper) Council; Monar (n 100) 135.

108 Hague Programme, Annex to the European Council Conclusions, Brussels, 4-5 November 2004, point 2.5. SitCen had originally dealt mostly with Second Pillar measures, monitoring on a constant basis potential threats. It has however expanded its remit into Justice and Home Affairs, providing strategic intelligence-based assessments on counter-terrorism matters: House of Lords Select Committee on the European Union, 'After Madrid: the EU's response to terrorism' HL (2004-5) Fifth Report, 61.
} 
such a body. ${ }^{109}$ No new structures should be created and reference to COSI was to be avoided. ${ }^{110}$ Rather, existing structures should be strengthened and made more efficient. A pilot project was set up in the field of organised crime, essentially proposing ways of bringing together chiefs of police and CATS, with the additional input of relevant agencies and working groups. Here one may raise a question as to Frontex's involvement. Until the Lisbon Treaty enters into force, Frontex competences are limited to those under the First Pillar. Although this in itself does not stand in the way of co-operation on issues such as irregular migration, its involvement in other activities aimed at fighting crime would have to be considered beyond its remit. ${ }^{111}$

The Council's document on the Architecture of Internal Security and the Council's Conclusions of 2008 seem to take only very small steps in the direction of a more centralised co-ordination of operational co-operation at EU level, referring once more to 'better co-ordination' and 'continuing reflection' on the functioning of the Council's working structures. At the same time, the six-monthly meetings between the JHA agencies and the presidencies of CATS and SCIFA have been in place since 2005 and have been intensified upon the recommendation of the Council. ${ }^{112}$ One of the first topics on the agenda was the exchange of information between these agencies. Importantly, it was decided by the heads of the EU JHA agencies that from now on the confidentiality rules/security regulations of other agencies, including those regulations governing classified information, would be considered as equivalent. ${ }^{113}$

The establishment of a Council Standing Committee on matters of internal security could cast an intergovernmental shadow over the management of external borders management, placing its co-ordination back into the sphere of influence of the Council. Much will depend on the final shape of COSI. If it is to function as the sole co-ordinator of operational co-operation in the AFSJ, this role could clash with that of Frontex in the area of external border management, since this agency was set up for this

109 Council (n 65) 1.

110 Council, Meeting on Coordination of Operational Cooperation: Summary of Discussion, Document 6290/06, 21 February 2006.

111 See in this respect the criticism by EU Counter-Terrorism Co-ordinator De Kerchove (n 94).

112 Council, 'Draft Conclusions on the future of Europol and Council recommendations implementing selected short term options' Council Document 16831/06, 20 December 2006, 5.

113 Council (n 78). Currently, information exchange between agencies is subject to confidentiality agreements. The obligation to conclude such agreements seems to flow from the agencies' own security regulations, which often copy the Council's Security Regulations. These require the conclusion of a confidentiality agreement prior to the exchange of information with third countries and/or international organisations. 
specific purpose and has deliberately been given a degree of independence to fulfil this task. If it is to take on more strategic tasks, it would essentially take over SCIFA's current role under Title IV EC, potentially weakening the Commission's recently acquired role of co-ordinating policy initiatives in the area of external border management.

\section{Current developments}

The fact that the ratification of the Lisbon Treaty in all Member States remains uncertain calls for a brief reflection on the future of the management of the external borders. Work on the integrated management of the EU borders is continuously under development, both in legislative and operational terms. In February 2008, the Commission tabled three communications which together were labelled 'the EU Border Package'. The first Communication evaluates FRONTEX and considers its future development, the second is entitled 'Preparing the next steps in border management in the European Union', and the third examines the setting-up of a European Surveillance System (EUROSUR). ${ }^{114}$ An in-depth discussion of these Communications would be beyond the scope of this article. For this reason, only a few elements will be highlighted here.

First, the Communications are characterised by the importance that is attached in them to technological solutions for surveillance and information exchange, attempting to 'virtually' seal off the EU's external borders. With regard to the next steps in EU border management, for instance, the Communication contemplates the possibility of introducing a system of registration for entry-exit for all third-country nationals, the use of automated gates at points of entry, a registered traveller status, and also an electronic travel authorisation system. The Communication on EUROSUR focuses on the establishment of a permanent system of surveillance and information-exchange at the EU's external maritime borders.

Second, both the EUROSUR and Frontex Communication show a continued focus on operational co-operation. The idea of establishing a European Corps of Border Guards is not abandoned, although there is no specific reference to such a corps. The Commission wishes to consider 'to what extent coordination of Member States' resources should be replaced with the assignment of border guards and equipment on a permanent basis. ${ }^{.115}$ It suggests that eventually the Agency itself might deploy border

\footnotetext{
114 Commission (EC) (n 2); Commission (EC) (n 68); Commission (EC), 'Preparing the next steps in border management in the European Union' (Communication) COM (2008) 69 final, 13 February 2008.

115 Commission (EC) (n 2) 10.
} 
guards, calling, however, for a review of the Agency's legal framework. Indeed, it must be asked on the basis of which treaty article these border guards would be endowed with public authority. The use of Article 62(2)(a) EC, which only refers to standards and procedures, would in my view stretch the scope of this article too far. Arguably, with the entry into force of the Lisbon Treaty, Article 77(2)(d) TEU could serve as the legal basis for this purpose, but whether this would also be politically feasible is a different question.

The Commission in its Communication on Frontex emphasises the importance of horizontal integration between border and customs authorities in order to achieve integrated border management. The Hague Programme has already stated that an evaluation of Frontex should examine whether 'the Agency should concern itself with other aspects of border management, including an enhanced co-operation with customs services and other competent authorities for goods-related security matters.'116 The Commission does appear rather reluctant in this respect, recommending merely a study on inter-agency co-operation and suggesting joint operations of Member States' border and customs authorities, co-ordinated by Frontex and the Commission. It seems that the Commission is reluctant to encroach upon the powers of its own DG Taxations and Customs.

As an overall comment on the 'border package', it can be said that it lacks a critical evaluation of achievements made so far and does not present a comprehensive vision for the future development of this policy area. ${ }^{117}$ Importantly, it almost completely ignores the question of human rights and international protection during operational co-operation, which has been fiercely criticised by Jeandesboz. ${ }^{118}$ The 2002 Communication was not only more ambitious, but also constituted a clear policy agenda. Instead, the 2008 Communications propose more of the same: increased powers for Frontex, intensified operational co-operation, more technological surveillance and additional data-collection. They do so without fully considering the implications of the measures proposed or their technical feasibility. ${ }^{119}$ Nonetheless, on at least one of the main

\footnotetext{
116 Hague Programme (n 108) point 1.7.1.

117 See also E Guild, F Geyer and S Carrera, 'The Commission's New Border Package - Does it Take us One Step Closer to a “Cyber-fortress Europe”?' (2008) CEPS Policy Brief No 154 (March) Brussels.

118 J Jeandesboz, 'Reinforcing the Surveillance of EU Borders: The Future Development of FRONTEX and EUROSUR' (2008) Challenge Research Paper No 11 (August) Brussels, 18.

119 It is for instance worrying that the Commission has proposed an entry-exit system twice already before, yet has never engaged in a thorough assessment of its technical feasibility: Commission (EC), 'Communication on improved effectiveness, enhanced interoperability and synergies among European databases in the area of Justice and Home Affairs' (Com-
} 
proposals, the introduction of an entry-exit system, there already seems to be broad agreement amongst Member States. ${ }^{120}$ The emphasis on operational co-operation as a means of advancing integration in the AFSJ through practical co-operation rather than substantial legislation, as is the case for the development of EUROSUR, remains subject to the criticism voiced above.

\section{Conclusion}

Even if the Lisbon Treaty does not enter into force, most of the measures proposed in the Commission's border package could still be adopted. However, it would be a lost opportunity for an increased democratic and judicial overview of the legislative measures that shape this policy. At the same time, one should realise that the focus of both this policy area and the AFSJ as a whole remains very much on the co-ordination of operational co-operation between national enforcement authorities, and that law enforcement activities are by their very nature operational tasks.

It will be necessary to give more thought to developing a sound legal framework for the EU's joint operational activity in the AFSJ as a whole and the management of the external borders in particular. This contribution has shown that the Lisbon Treaty, although distinguishing legislative acts from non-legislative acts, as well as legislative activity from operational activity, fails to do so. It has been argued that although Member States' judiciaries have the prime responsibility in ensuring respect for fundamental rights by their respective border-guard authorities, the ECJ should have a subsidiary power of judicial review when it comes to guaranteeing respect for the Union's core values and their full effectiveness in the implementation of this Community policy.

When the Treaty of Lisbon enters into force, the broad reformulation of the legal bases for the adoption of measures for the management of the external borders arguably leaves the Community legislator with considerable leeway to adopt legislative measures for a truly integrated system

munication) COM (2005) 597 final, 24 November 2005, 9; Commission (EC), 'Communication on Policy priorities in the fight against illegal immigration of third-country nationals' (Communication) COM (2006) 402 final, 19 July 2006, 6.

120 See replies to a questionnaire from the Council Presidency: 'Project for a system of electronic recording of entry and exit dates of third-country nationals in the Schengen area' Council Document 13403/08, 24 September 2008. Nineteen Member States, including the UK and Ireland, who are not even participating in the EU's external border policy, as well as the three SAC countries replied. Only two Member States (Slovenia and Romania) opposed the taking of biometric data, Lithuania's answer was unclear and Hungary wanted the taking of biometric data only for those TCN under a visa obligation. Greece went as far as to argue the entry-exit system should extend even to EU citizens, which would be contrary to the EU free movement rules as they stand. 
of external borders management. Practice would, however, need to show whether such measures would be adopted under the legal basis for the management of the external borders or under the chapter for police cooperation. Moreover, it remains to be seen how far this legal competence would allow for the conferral not just of co-ordinating powers, but also executive powers concerning 'EU border guards'. Although politically this would seem controversial, the possibility should not be excluded, bearing in mind the importance that Member States and the Community attach to tackling irregular migration.

The Hague Programme will expire in 2010 and preparations for its follow-up, the Stockholm Agenda, to be adopted under the Swedish Presidency, are underway. ${ }^{121}$ It is to be regretted that with regard to the external borders policy, the 'EU future group', charged with the task of giving more thought to the future development of the AFSJ when the Hague Programme ends, simply echoes the Commission's border package. ${ }^{122}$ These Communications, however, lack a well-thought-through vision of the future direction of the EU's policy in this area. Whether the Lisbon Treaty will enter into force or not, it is desirable that the Stockholm Agenda gives clear guidance for the future direction of the AFSJ as a whole and external borders management in particular. If it does enter into force, it should give guidance on how the Community intends to use its competences in this field and how it envisages the relationship between the former First and Third Pillars, not merely in terms of legislation but also in terms of operational co-operation.

121 See, for instance, the public consultation on the future of the AFSJ launched by the Commission: <http://ec.europa.eu/justice_home/news/consulting_public/0001/consultation_questionaire_en.pdf> last accessed 15 April 2009.

122 Report of the Informal High Level Advisory Group on the Future of European Home Affairs Policy (The Future Group), 'Freedom, Security, Privacy - European Home Affairs in an Open World' (June 2008) 36. The EU Future Group was established by the German Presidency in 2007 and drafted recommendations for when the Hague Programme ends (2010) <http://www.statewatch.org/news/2008/jul/eu-futures-jha-report.pdf > last accessed 15 April 2009. 